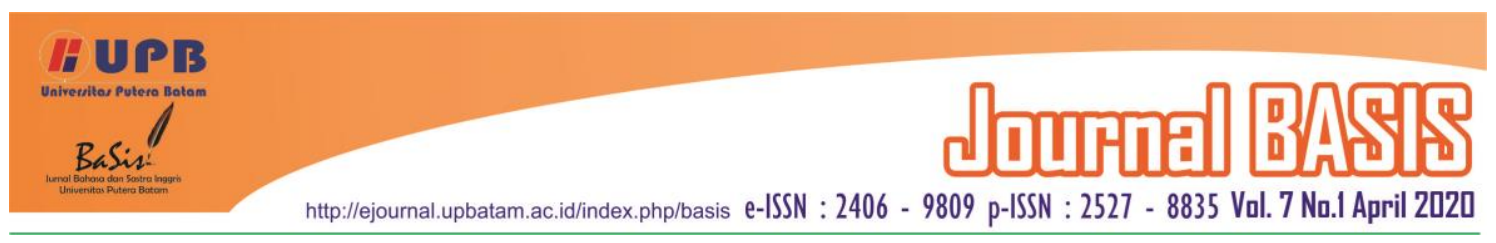

\title{
STUDENTS' PERCEPTIONS ON THE USE OF INTERNET AS LEARNING MEDIA IN READING CLASSROOM
}

\author{
Nurhasanah $^{1}$ \\ Universitas Baturaja, Palembang, Indonesia \\ nurhasanah@fkip.unbara.ac.id \\ Bambang Sulistyo ${ }^{2}$ \\ Universitas Baturaja, Palembang, Indonesia \\ bambangsulistyo@unbara.ac.id \\ Merie Agustiani ${ }^{3}$ \\ Universitas Baturaja, Palembang, Indonesia \\ merie_piecery@fkip.unbara.ac.id \\ Eviyatin Nisa Ulya ${ }^{4}$ \\ Universitas Baturaja, Palembang, Indonesia \\ eviyatinnisaaulya@gmail.com
}

\begin{abstract}
This study investigated students' perception of using the internet as learning media in reading comprehension skills. This study uses descriptive statistics. The objective of the research was to find out the students' perception of using the internet as learning media in the reading comprehension skill of the English Education Study Program at Baturaja University. The population of this research was 79 students of English Study Program. The researcher only took 54 students as the sample by applying purposive sampling. The data was collected through the questionnaire that consisted of 20 statements. Then the researcher used five points of Likert scale for analyzing the data. The result of this research there agreed (4.03) students had a positive perception of using the internet as learning media in reading comprehension skills. It means that the internet is a facility to improve his proficiency in language skills. So the use internet for English learning makes language learning an easier process by being fun, interactive, and interesting.
\end{abstract}

Keywords: Internet; learning media; reading classroom; students' perception

\section{INTRODUCTION}

English plays a crucial role in global activities such as buses, communications, education, and many other life aspects. English is considered a dominant language in the world for the transfer of information and technology in this period of globalization. On the other hand, In popularizing English as a global language, new media-particularly the Internet may play an important role. It says English is a significant medium in science growth. English is the first foreign language taught in Indonesia, 
from elementary to universities (Sudiran, 2015).

There are several skills that the students must master to achieve the goal, for example in reading. Reading understanding is one of the basic language skills enabling learners to enhance their achievement. Through reading comprehension, learners can give new experiences that will become the basis for knowledge acquisition. EFL students are unlikely to make further progress without being exposed to reading materials in the classroom (Floris \& Divina, 2009). Unfortunately, students are often unwilling to complete individual lecture assignments in subject area texts leaving teachers with few choices in the content area. Teachers will continue to assign independent reading with the expectation that some students can complete the reading or give up reading assignments and simply provide relevant information to students (Whittingham, 2014).

Media is an instrument that can generate learning curiosity and promote the interest. Sudiran (2015) describes that reading is also very important for learners to improve their knowledge and skills. Therefore students are suggested to enhance their reading skills. They need to find a medium that can improve their ability to read through many media, such as the Internet. The internet can be described as a large global computer network linking computer users from one country to another worldwide, where there is a range of knowledge from static to dynamic and interactive. Fast in all aspects of human life, the Internet has been extensive. In terms of education, the internet is regarded as the easiest method for obtaining education-related information, literature, or references (Syawal et al., 2017).

In the 20th century the Internet rapidly reached human life. It took less than ten years for us to face the fact that it has spread throughout the world, including the developing countries. Since then it has become the world's hugest intelligence network, but - most importantly - the quickest means of communication. Concerning students who are naturally known as active internet users, the use of the internet is mostly for social and entertainment purposes, as the internet revolution is not only about finding information but also bringing people together. It is, however, very obvious that the Internet not only provides social connection and entertainment but also academic and scientific information (Dogruer et al., 2011). Through the internet, anyone studying at schools, universities, colleges can use educational literature, encyclopedia, guides, dictionaries, publicly accessible databases, engaging in distance learning courses, collaborative projects with students from other schools, universities, countries, discussing various issues.

At Baturaja University, the internet becomes a common supplementary resource for the students, not only in learning English but also in all the courses they have taken part in. The writers, therefore, wanted to investigate deeply the perception of the students regarding the use of the internet as their learning media, especially in the English reading classroom.

\section{LITERATURE REVIEW}

2.1. Internet as Learning Media 
The Internet is a network of people and information, linked together by computer-connected telephone lines. On this path, there are many ways to move information through the different computer systems, such as e-mail and the World Wide Web. Media plays an important part in the process of language learning. Students can easily comprehend the lessons through the media. The Internet creates an interesting learning experience too. The use of media should be acceptable for the learning goals. The media is used to help learners understand the learning materials. Sudiran (2015) describes in terms of media, The Internet can be used as a structured teaching media support center. The Internet can be used as part of the electronic media to enhance student interest in many subjects.

The use of internet technology has evolved tremendously in education. Online courses that can or cannot provide interaction between teacher and student become the most common form of qualitative education. Further, Internet technologies can transform teaching and learning processes by offering educators and students alternative solutions in the allocation of the latest information, access to virtually unlimited resources and opportunities for real-world communication, collaboration and competition (Abdullahi et al., 2014).

\subsection{Reading Comprehension}

Reading is one of the most important skills for knowledge growth alongside listening, speaking, and writing. Comprehension is a major goal to read. It means a reader should have a good understanding of a deep understanding of the text. According to Johnson (2008), "If there is no meaning, there is no reading taking place." that reading comprehension conceived as a process requiring readers to construct conceptual knowledge from text through cognitive interaction and involving the motivation of the reader to use the text (Guthrie et al., 2004).

Reading comprehension is one of the basic language skills allowing learners to improve their achievement. Through reading comprehension, Learners can gain new experiences through reading comprehension, which becomes the foundation for knowledge acquisition. A student can appreciate other people's experiences through books or other printed sources. Therefore, reading comprehension is a fundamental skill for everyone who wants to improve their insight. According to Sudiran (2015) reading is a skill that leads all people to achieve their goals of life.

Above all, reading understanding is a dynamic and active process that allows readers to connect with the text to get the full meaning and appreciate the concept that the writer wants to express in his / her writing

\subsection{The Use Internet in Reading Classroom \\ Internet applications play an} important role in encouraging and making students more efficient and active in the educational process. The rapid evolution of information and communication technology (ICT) has had many different effects on English teaching. The Internet is an accurate possible source of materials. Recovering, accessing and using knowledge in the sense of international second language learning is both useful and easy (Aydin, 2007).

The Internet can be effective tools and resources for the design of 
activities in the classroom, such as language skills, and especially in reading comprehension. Using internet applications allows teachers and students to gain access to a variety of reading text that helps improve the reading comprehension skills of the students. Students who improve their English reading skills via various software programs or Internet resources find that global interactions through forum boards and blogging enable them to make personal links with others learning at their speed, and also provide them with support and guidance along the way. As Marzban (2011) explains that research suggests that ICT has the most beneficial effect on languages of teaching and learning where it is focused at specific areas, with a specific justification for its use from a large ICT, pedagogical and professional development research base. In English language learning, ICT can increase possibilities to use first languages to support education and English learning, for example through internet translation tools, electronic bilingual dictionaries, first-language text related to the subject matter, and online explanations.

\subsection{Related Previous Study}

Many researchers had investigated concerning on the right teaching methods for speaking skills (Hakim \& Suniar, 2019; Haliwanda, 2019; Hulu \& Ambalegin, 2018). Various methods and media were used to find out the right way to minimize students' difficulties in speaking so that they could improve their speaking learning achievement. As well as the use of the internet in learning English, many instructional media platforms using the internet as media are tested for their effectiveness in improving student learning outcomes (Hung, 2015;
Irawati, 2016; Kabilan et al., 2010; Namaziandost \& Nasri, 2019; Shin \& Son, 2007; Wulandari, 2019). This study was conducted by referring to previous that hopefully can give more contribution to English language teaching.

\section{RESEARCH METHOD}

\subsection{Method of the Research}

The researcher has used the descriptive method in this investigation. The descriptive method used to analyze the gathered data objectively based on the fact that it would be found. (Sugioyono, 2010) explains the descriptive approach is statistics that using to analyze the data in ways that explain data that collecting as without intending to make a valid conclusion.

\subsection{Participants of the Research}

In this research the population of this research was the students of the English Education Study Program at Baturaja University. In the academic year of 2018/2019 the total of number students was 79 students. Besides, a sample is a subset of the individuals in a population; Individual data usually are available in samples. Sampling is the method of choosing several individuals for a sample to represent the larger population from which they were chosen. In this research, the researcher used purposive sampling. According to (Sugioyono, 2015) purposive sampling is the method of selecting samples by taking subjects that are not based on the level or region but are based on a specific purpose. For this research, the researcher took only in semester 2, 4, and 6, which means the total number of the sample was 54 students. 


\subsection{Data Collection and Analysis}

The data of this study is collecting by a questionnaire. In this research, the questionnaire was used to collect data from the respondents and to assess the perception of students using the Internet as a learning tool in reading comprehension skills. The questionnaire consisted of 2 parts; biographical information of students, and perceptions of students. There were 20 statements constructed from a ready-made student perception questionnaire developed by Sudiran (2015). After gathering the data, the researcher used descriptive statistics and analyzed the data by using SPSS 21. The scores of the questionnaire were the total number of options given by the respondents. The values obtained from the data analysis were used to formulate the findings.

\section{RESULTS AND DISCUSSIONS}

4.1 The Result of Students' Perception of the Use of the Internet

Based on the results of this study, the researcher found that the perception of the students of the English Education Study Program at Baturaja University was agreed on reading comprehension skills towards the internet as learning media. It could be seen from the average of 54 students they answered "agree" with the Mean score $(M=4.03)$ and Std. Deviation $(\mathrm{SD}=0,471)$. There were $29(53.7 \%)$ out of 54 students who agreed that the internet was helpful for them. This means students had a positive perception of using the internet. Considering the mean score of the data analysis, it can be concluded that the students tend to use the internet as media to gain information positively in everyday life.

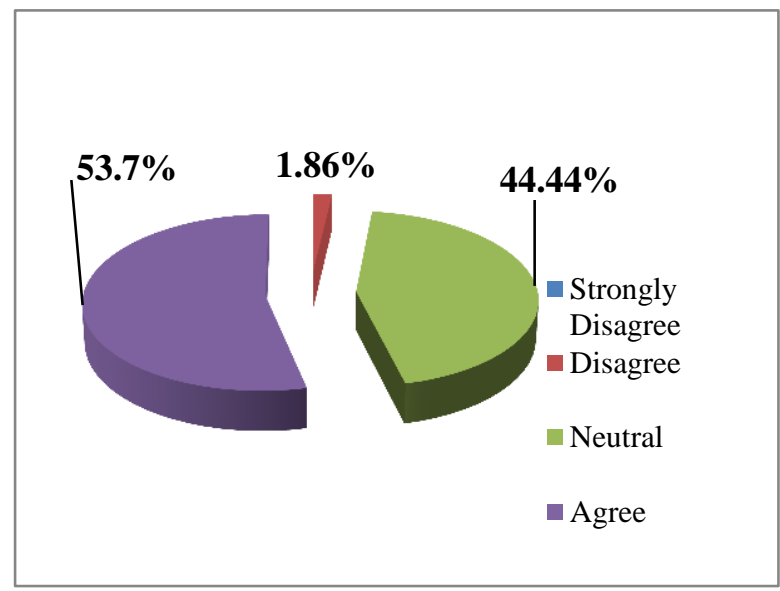

Diagram 4.1. Students' Perception of the Use Internet in General

This finding was quite similar with the study of Aydin (2007) EFL who found that learners have positive attitudes toward the internet. The learners considered internet as a universal library, the best way to teach information, a place that builds strong social relationships, an effective training resource, and a way to provide people with learning to look for. The Internet has profoundly affected almost every aspect of our lives, changing the way we do business, communicate and even educating ourselves (Kia Heirati \& Ahmadi Alashti, 2015).

Internet users come from various places around the world, using a range of computer programs and software. Certain terms are used, and some standard rule generally applied is made to use the Internet together. The Internet itself presents broad types of services. Internet services are popular today and are commonly used, including email, chatting, data file transfer, and web (Jasmadi, 2004).

A study revealed by Alzahrani \& O'Toole (2017) that investigated student experience with the internet and their attitudes towards using it also found that the students seemed to have 
a positive attitude toward the Internet. The Internet is likely to become an increasingly important way for students to keep new information up-to-date as it emerges. This may well affect future curriculum design, and this study suggests that student preference for one learning approach over other needs to be taken into account by instructional designers.

\subsection{The Result of Students' Perception} of the Use Internet as Learning Media

Based on the data above, it could be seen from the average of 54 students they answered "agree" with the Mean score $(\mathrm{M}=3.92)$ and Std. Deviation ( $\mathrm{SD}=0.38$ ). It means that students' perception of the use of the internet was positive. We could see that students learned the benefits of using the internet for them, so the learners could understand more easily.

This finding was similar to the study of Al Otaibi (2012) who investigated the relationship between the attitude towards the use of the Internet and its cognitive, emotional and behavioral components. In accordance to the attitudes of the person towards the internet, a large number of study sample participants (85.6\%) accepted that the internet is a high-speed means of information gathering, a good source of information $(68.1 \%)$ and a good means of continuous self-learning $(69.4 \%)$.

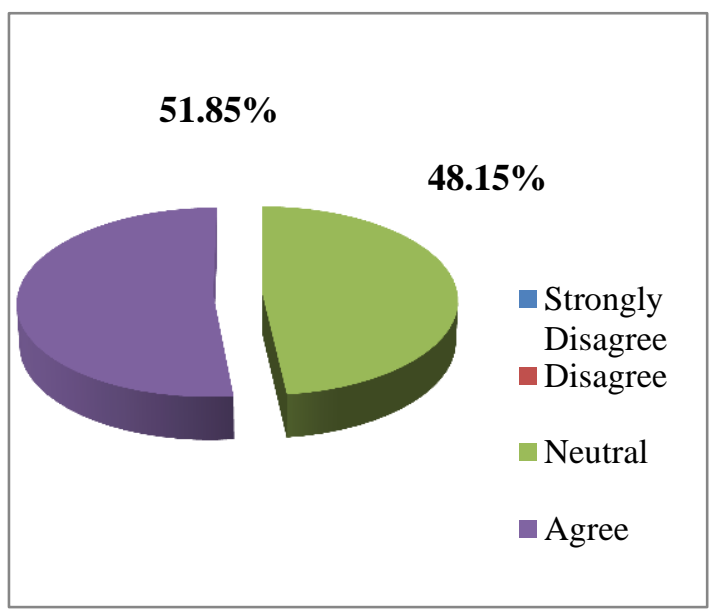

Diagram 4.2. Students' Perception of the Use Internet as Learning Media

Media is important in the learning process at university. Kia Heirati \& Ahmadi Alashti (2015) mention that it should be noted that learners ' views of technology and their presence as teaching devices in their English classes can have a significant impact on the success or failure of teaching and learning processes.

Technology has always been an important part of the context of teaching and learning. This is an important part of the role of teachers in which they can use this to promote learning for the learners. When we speak about technology, the term 'integration' is used in teaching and learning. Despite technology forming part of people's everyday lives, it's time to rethink the idea of integrating technology into the curriculum and aim to implement technology into teaching to facilitate the learning process (Ahmadi, 2018). Sudiran (2015) claimed that the internet can be used in media terms as a systematic supporting learning media facility. A lecturer can use a computer with all its programs in the teachinglearning process to improve the learning achievement of the students. The existence of the Internet will enhance 
teaching and learning activities in the classroom. The use of the Internet in the classroom will make the atmosphere of learning more desirable and alive. This is because the Internet can provide a range of learning materials in the relevant information.

\subsection{The Result of Students' Perception} of the Use Internet in Reading Classroom

Based on the data above, it could be seen from the average of 54 students they answered "agree" with the Mean score $(\mathrm{M}=4.25)$ and Std. Deviation $(\mathrm{SD}=0.49)$. It means that students' perception has a positive perception of the internet it as a facility to improve his proficiency in language skills especially in reading comprehension.

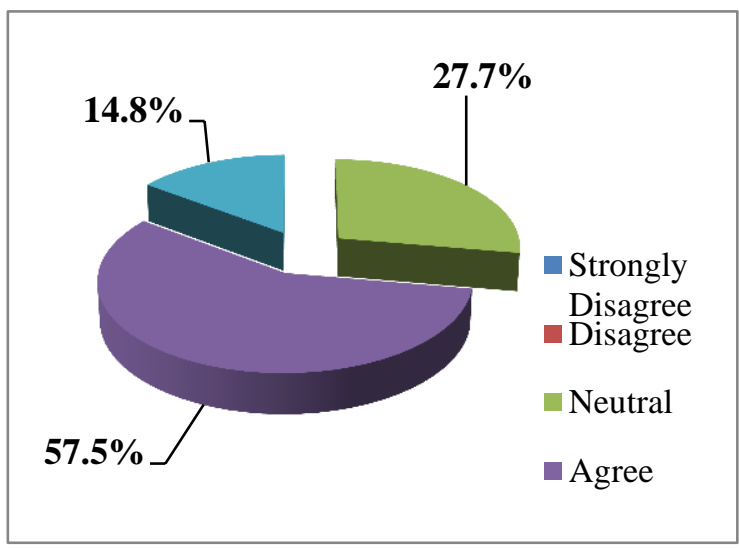

Diagram 4.3. Students' Perception of the Use Internet in Reading Classroom

Kalangi et al. (2019) point out that in learning English, reading in this case, it's an issue when students are unable or unable to get the point of the written text they have read. The teachers should also be innovative, and have an important role to play. Internet browsing is one of several ways that can be used for teaching and learning practices. Using technology in English Language Teaching is usually not only to make teaching and learning process more interesting, but it can also facilitate learners in learning English, especially in reading processes.

Students are perceived to have a positive perception of the use of information and communication technology or the Internet in the context of reading comprehension when they think the Internet is an important tool for enhancing their reading skills. Students often had access to the Internet to obtain reading materials suitable for their assignment of reading. The Internet is one of the effective ICT resources that can be used in many various methods to teach language skills. This assists in motivating teachers to use ICT tools to keep students for learning in the classroom. According to (Jafari et al., 2014), the growth in the application of ICT technologies has allowed teachers to access the resources available in pedagogical and educational technology through advances in computer-assisted instruction (CAI) and language learning (CALL).

The study of Sudiran (2015) showed the fact that the overall percentage of students responding to the questionnaire was between $87.2 \%$ and $92.9 \%$ concerning their frequency level of Internet access. This meant that students had high-frequency internet access as learning media to promote their achievement in reading. Another study by Vega et al. (2019) revealed that in all measurements collected, students received better scores when reading eighth-grade texts in groups with Internet access as opposed to reading independently without internet access. 


\section{CONCLUSION}

Numerous studies and several researchers have inspected the influence of technology on education in EFL / ESL settings and contexts. This study was also aimed at finding out how was the students' perception toward the use of the internet for supplementing their learning process. Based on the result of the data analysis, the researcher concluded that students had a positive perception of using the internet as learning media in reading comprehension. The finding of this study showed that students find the internet to be an essential tool to improve their learning success, especially in reading. To do so, they will spend a good deal of time on the internet to access information. This finding is evidence that students have a favorable understanding of the use of the internet in learning to understand the reading subject. The Internet can be effective tools and resources for the design of activities in the classroom, such as language skills, and particularly in reading comprehension. It means that using the internet as a learning tool can also help students interact with each other to make language learning more enriching and impact learners and learning processes.

\section{REFERENCES}

Abdullahi, S., Ransom, E. N., \& Kardam, M. S. (2014). The Significant of Internet Technology to Education and Students in Acquiring Quality Education. International Letters of Social and Humanistic Sciences, 32(1), 145153.

https://doi.org/10.18052/www.scip ress.com/ilshs. 32.145

Ahmadi, M. R. (2018). The Use of
Technology in English Language Learning: A Literature Review. International Journal of Research in English Education (IJREE), 3(2), 115-125. https://doi.org/10.29252/ijree.3.2.1 15

Al Otaibi, K. (2012). Attitudes towards the Use of the Internet. Psychology Research, 2(3), 151-159.

Alzahrani, M. G., \& O’Toole, J. M. (2017). The Impact of Internet Experience and Attitude on Student Preference for Blended Learning. Journal of Curriculum and Teaching, 6(1), 65-78. https://doi.org/10.5430/jct.v6n1p65

Aydin, S. (2007). Attitudes of EFL Learners towards the Internet. Tojet - The Turkish Online Journal of Educational Technology, 6(3), $18-26$.

https://www.researchgate.net/publi cation/274705061_Attitudes_of_E FL_learners_towards_the_Internet

Dogruer, N., Eyyam, R., \& Menevis, I. (2011). The use of the internet for educational purposes. Procedia Social and Behavioral Sciences, 28, 606-611. https://doi.org/10.1016/j.sbspro.20 11.11.115

Floris, F. D., \& Divina, M. (2009). a Study on the Reading Skills of Efl University Students. TEFLIN Journal, 20(1), 37-47. https://doi.org/10.15639/teflinjourn al.v20i1/37-47

Guthrie, J. T., Wigfield, A., \& Perencevich, K. C. (2004). Motivating Reading Comprehension. In Motivating 
Reading Comprehension.

Lawrence Erlbaum Associates, Inc. https://doi.org/10.4324/978141061 0126

Hakim, L. N., \& Suniar, Y. (2019). Socio-Affective Strategies in Enhancing Students' Speaking Motivation. Jurnal Basis, 6(1), 125-133.

https://doi.org/10.33884/basisupb.v $6 \mathrm{i} 1$

Haliwanda, U. (2019). The Effect of Using Direct Method in Teaching Speaking Skill At the Second Year of SMK Negeri 1 Bener MeriahAceh. Jurnal Basis, 6(2), 155. https://doi.org/10.33884/basisupb.v 6i2.1411

Hulu, F., \& Ambalegin, A. (2018). Efektivitas Direct Method Dalam Peningkatan Kemampuan Berbicara Bahasa Inggris Mahasiswa. Jurnal Basis, 5(2), 21. https://doi.org/10.33884/basisupb.v $5 \mathrm{i} 2.814$

Hung, H. T. (2015). Flipping the Classroom for English Language Learners to Foster Active Learning. Computer Assisted Language Learning, 28(1), 81-96. https://doi.org/10.1080/09588221.2 014.967701

Irawati, D. (2016). Supporting Student's English Speaking Achievement Using Video. International Journal of EFL, 1(1), 45. https://doi.org/10.21462/ijefl.v1i1. 5

Jafari, D., Dabaghi, A., \& Vahid Dastjerdi, H. (2014). The effects of Integrating ICT Resources into Reading Comprehension in Iranian
High School. International Journal of Research Studies in Language Learning, 4(2), 57-68. https://doi.org/10.5861/ijrsll.2014. 851

Jasmadi. (2004). Panduan praktis menggunakan fasilitas internet. CV. Andi.

Johnson, A. M. (2008). The Effectiveness of Contextualization on Second Language Acquisition using the Situational Discourse Semantic Model. Louisiana State University.

Kabilan, M. K., Ahmad, N., \& Abidin, M. J. Z. (2010). Facebook: An online environment for learning of English in institutions of higher education? Internet and Higher Education, 13(4), 179-187. https://doi.org/10.1016/j.iheduc.20 10.07 .003

Kalangi, M., Liando, N., \& Maru, M. (2019). The Effect of Applying Internet Browsing in Improving Students' Reading Comprehension Skill. 383(Icss), 947-951. https://doi.org/10.2991/icss19.2019 .66

Kia Heirati, J., \& Ahmadi Alashti, L. (2015). Attitudes toward using the Internet for Language Learning: A case of Iranian English Teachers and Learners. International Journal of Research Studies in Educational Technology, 4(1). https://doi.org/10.5861/ijrset.2015. 1029

Marzban, A. (2011). Improvement of Reading Comprehension through Computer-Assisted Language Learning in Iranian Intermediate 
EFL Students. Procedia Computer Science, 3, 3-10. https://doi.org/10.1016/j.procs.201 0.12 .003

Namaziandost, E., \& Nasri, M. (2019). The Impact of Social Media on EFL Learners' Speaking Skill: A Survey Study Involving EFL Teachers and Students. Journal of Applied Linguistics and Language Research, 6(3), 199-215.

Shin, H.-J., \& Son, J.-B. (2007). EFL teachers' perceptions and perspectives on internet-assisted language teaching. ComputerAssisted Language Learning Electronic Journal (CALL-EJ), $8(2), 1-13$.

Sudiran. (2015). Students' Perception Towards the Use of Internet as Learning Media to Promote Reading Comprehension Skill. Sino-US English Teaching, 12(9), 684-692.

https://doi.org/10.17265/15398072/2015.09.007

Sugioyono. (2010). Metode penelitian kuantitatif kualitatif dan $R \& D$. Alfabeta.
Sugioyono. (2015). Statistik untuk penelitian. Alfabeta.

Syawal, S., Patahuddin, P., \& Nasrullah, N. (2017). The Effect of Internet on English Learners Learning Behavior. 4(November). https://doi.org/10.26858/eltww.v4i 2.4399

Vega, N., Stanfield, J., \& Mitra, S. (2019). Investigating the Impact of Computer Supported Collaborative Learning (CSCL) to Help Improve Reading Comprehension in Low Performing Urban Elementary Schools.

https://link.springer.com/article/10. 1007/s10639-019-10023-3

Whittingham, J. (2014). Reading Motivation: A Study of Literature Circles. Academic Exchange Quarterly, 18(2).

Wulandari, M. (2019). Improving EFL Learners' Speaking Proficiency Through Instagram Vlog. Journal on Language and Language Teaching, 22(1), 111-125. https://doi.org/10.24071/1lt.2019.2 20111 